\title{
Effect of salicylic acid in two stages of application on wheat crop
}

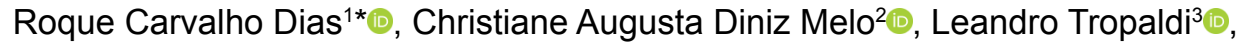 \\ Paulo Vinicius Silva ${ }^{4} \odot$, Daniel Valadão Silva ${ }^{5}$, Marcelo Rodrigues Reis $^{6}{ }^{\circ}$ \\ ${ }^{1}$ Universidade Estadual Paulista, Botucatu, SP, Brasil. E-mail: roquediasagro@gmail.com \\ ${ }^{2}$ Universidade Federal do Triângulo Mineiro, Iturama, MG, Brasil. E-mail: christiane.melo@uftm.edu.br \\ ${ }^{3}$ Universidade Estadual Paulista, Dracena, SP, Brasil. E-mail:I.tropaldi@unesp.br \\ ${ }^{4}$ Universidade Federal da Grande Dourados, Dourados, MS, Brasil. E-mail: paulovsilva@ufgd.edu.br \\ ${ }^{5}$ Universidade Federal Rural do Semi-Árido, Mossoró, RN, Brasil. E-mail: danielvaladaos@yahoo.com.br \\ ${ }^{6}$ Universidade Federal de Viçosa, Rio Paranaíba, MG, Brasil. E-mail: reisagro@gmail.com
}

ABSTRACT: Salicylic acid (SA) is a plant growth regulator and participates in several physiological and biochemical processes. Its use can assist in the growth, development, productivity and quality of several crops. Thus, the objective of this work was to evaluate the effect of salicylic acid in two application stages on wheat crop. The experiment was conducted under field conditions and designed as randomized blocks, with four replications. Treatments 0.5 and $1.0 \mathrm{mM}$ of SA were applied in stages 1 and 10 , beginning and end of vegetative growth of wheat plants, besides a control treatment (without SA). Phytointoxication and SPAD index evaluations were performed at 14, 21, 28, and 35 days after application (DAA) of SA and the end of the experiment, 109 DAA the plants were tracked to quantify the mass of a thousand grains, hectoliter weight and grain yield. The application of SA did not cause symptoms of phytointoxication and increased the values of the SPAD index and all components of grain yield compared to the control treatment (without SA). The application of SA promoted a greater increase in the variables analyzed when applied in stage 10 of wheat plants.

Key words: grain yield; growth regulator; Poaceae; Triticum aestivum L.

\section{Efeito da aplicação de ácido salicílico em diferentes estádios da cultura do trigo}

RESUMO: O ácido salicílico (AS) é um regulador de crescimento de plantas e participa de diversos processos fisiológicos e bioquímicos. Seu uso pode auxiliar no crescimento, desenvolvimento, rendimento de grãos e qualidade de diversas culturas. Assim, o objetivo desse trabalho foi avaliar o efeito do ácido salicílico em dois estádios de aplicação na cultura do trigo. 0 experimento foi realizado em campo no delineamento em blocos casualizados com quatro repetições. Os tratamentos $0,5 \mathrm{e}$ $1,0 \mathrm{mM}$ de AS foram aplicados no estádio 1 e 10, início e final do crescimento vegetativo, respectivamente, das plantas de trigo, além de um tratamento controle (sem AS). Foram realizadas avaliações de fitointoxicação e índice SPAD aos 14, 21, 28 e 35 dias após a aplicação (DAA) do AS e ao final do experimento, 109 dias após a semeadura as plantas foram trilhadas para quantificação da massa de mil grãos, peso do hectolitro e rendimento de grãos. A aplicação de AS não provocou sintomas de fitointoxicação e aumentou os valores do índice SPAD e todos os componentes do rendimento de grãos em comparação ao tratamento controle (sem AS). A aplicação de AS promoveu maior incremento nas variáveis analisadas quando aplicada no estádio 10 das plantas de trigo.

Palavras-chave: rendimento de grãos; regulador de crescimento; Poaceae; Triticum aestivum L.

\footnotetext{
* Roque Carvalho Dias - E-mail: roquediasagro@gmail.com (Corresponding author)

Associate Editor: Henrique Pereira dos Santos
} 


\section{Introduction}

Wheat (Triticum aestivum L.) stands out as a winter crop with great economic relevance, given its high adaptability to different environmental conditions, high productive capacity and the nutritional quality of the grains (Marini et al., 2011). In Brazil, in 2020, the estimated cultivation area was 2,390 thousand hectares with an estimated production of 6.4 million tons (Conab, 2020). Although genetic improvement is an important tool within the agricultural research system, there is an increasing search for other tools that aim to increase the grain yield of crops with the least possible environmental impact. In this sense, the use of plant regulators is a practice that aims to improve the grain yield and nutritional quality of crops. These compounds can promote rooting, flowering and fruit growth, leaf and fruit abscission, senescence, regulation of some metabolic processes, and plant resistance to biotic and abiotic stresses (Taiz et al., 2017).

Salicylic acid (SA) is a signaling compound and signal amplifier of phenolic origin, which is related to several regulatory functions in plant metabolism (Mazzuchell et al., 2014). Exogenous application of SA, at low concentrations, enhances pathogen control response and induction of disease resistance (Rivas-San Vicente \& Plasencia, 2011), plays an important role on germination, regulation of plant growth and development (Sharafizad et al., 2013), fruit production, water and nutrient uptake and transport (Hayat et al., 2010b), photosynthetic rate, stomatal conductance and transpiration (Hayat et al, 2010a), acts as an important non-enzymatic antioxidant agent, activating the response and defense mechanisms to environmental stresses (Hayat et al., 2010a; Kang et al., 2014), herbicide intoxication (Dias et al., 2017), as well as increasing the biomass of the aerial part (VillanuevaCouoh et al., 2009), plant roots (Martín-Mex et al., 2013) and grain yield (Martín-Mex et al., 2012) of treated plants.

In Poaceae species Khodary (2004), found that applications of $10 \mathrm{mM}$ SA in maize accelerated Rubisco enzyme activity, increasing photosynthetic activity and growth components such as height, fresh and dry root and aboveground biomass. Concentrations of $0.01,0.1$, and $1 \mu \mathrm{M}$ of SA increased the growth and root development of maize plants (Tucuch-Haas et al., 2016). In field studies by Tucuch-Haas et al. (2017), applications of 0.1 and $1.0 \mu \mathrm{M}$ to corn seedlings promoted increments in grain yield and nitrogen, $\mathrm{P}_{2} \mathrm{O}_{5}$, and $\mathrm{K}_{2} \mathrm{O}$ contents.

In wheat, Hayat et al. (2005) observed that seeds soaked in $10 \mu \mathrm{M}$ of SA stimulated nitrate reductase activity, increasing the fresh and dry biomass of the plants. Similarly, for the 0.5 $\mathrm{mM}$ concentration (El Tayeb \& Ahmed, 2010) found higher sugar, protein and dry biomass content of wheat plants. Shakirova (2007), observed higher germination rate and better growth of wheat seedlings when treated with SA. Already in foliar applications of $1 \mu \mathrm{M}$ of SA over the canopy of wheat seedlings increased root fresh biomass, plant height, and total fresh biomass (Tucuch Haas et al., 2015).

In the literature, SA has been reported to be responsible for the increase in grain yield of tomato (Solanum lycopersicum
L.) (Larqué-Saavedra et al., 2010), pepper (Capsicum annuum L.) (Sánchez-Chávez et al., 2011), papaya (Carica papaya L.) (Martín-Mex et al., 2012) pepper (Capsicum chinense Jacq.) and cucumber (Cucumis sativus L.) (Martín-Mex et al., 2013). Thus, the involvement of SA in physiological and biochemical processes in plants, especially in Poaceae species Tucuch-Haas et al. (2017), suggest that this compound may induce higher grain yield in wheat crop. In addition, it is necessary to identify the most appropriate time to apply SA to the wheat crop.

Given the importance of the wheat crop in human nutrition and the action and importance of SA on plant growth and development, the objective of this work was to evaluate the effect on grain yield and grain yield components of salicylic acid application at two developmental stages of the wheat crop.

\section{Materials and Methods}

The experiment was conducted in the experimental area of COOPADAP (Cooperativa Agropecuária do Alto Paranaíba), in Rio Paranaíba, MG, Brazil, under an irrigated system, latitude $19^{\circ} 12^{\prime} 21^{\prime \prime} \mathrm{S}$, longitude $46^{\circ} 10^{\prime} 05^{\prime \prime} \mathrm{W}$ and altitude $1,140 \mathrm{~m}$. The climate is of type Aw, tropical with a dry season according to Köppen international classification. Weekly data on rainfall $(\mathrm{mm})$ and minimum and maximum air temperature $\left({ }^{\circ} \mathrm{C}\right)$ was collected from an automatic weather station present in the area during the entire period of the experiment (Figure 1). The soil is classified as Red-Yellow Latosol, with a very clayey texture (Embrapa, 2013).

A randomized block design with four repetitions was used. The dimensions of each experimental plot were $2.0 \times 12.0 \mathrm{~m}$, with a usable area of four meters in the center, leaving aside $0.5 \mathrm{~m}$ on the sides and four meters on each end, totaling $4 \mathrm{~m}^{2}$. Treatments were applied according to the modified Feekes \&

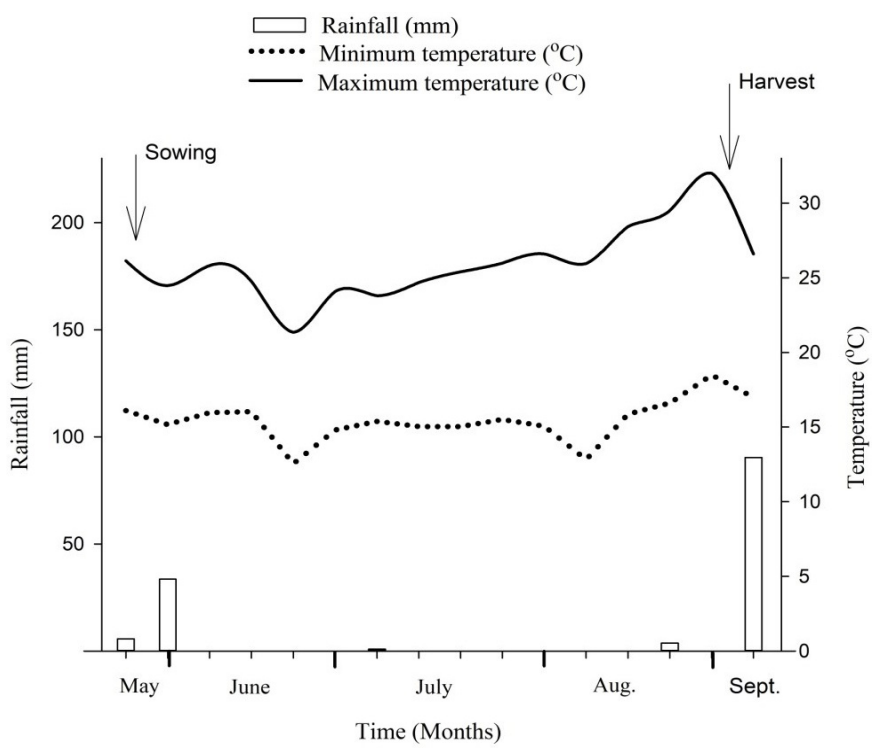

Source: Elaborated by the authors.

Figure 1. Weekly rainfall $(\mathrm{mm})$, minimum and maximum temperatures $\left({ }^{\circ} \mathrm{C}\right)$ daily from May 29 - sowing, to September 15, 2015 - wheat harvest. Rio Paranaíba, MG, Brazil. 
Large scale (Large, 1954) at stage 1 (emergence of coleoptile and first leaves): 0.5 and $1.0 \mathrm{mM} \mathrm{SA}$, at stage 10 (sprouting): 0.5 and $1.0 \mathrm{mM}$ and control (no SA), totaling five treatments. According to Rodrigues \& Teixeira (2010) the vegetative stage represents the periods from germination to the double-ring stage (floral initiation), used to mark the end of the vegetative phase.

For the application of the treatments a $\mathrm{CO}_{2}$ pressurized sprayer was used at 2 bar pressure, equipped with a boom with 110.02 ("fan" type) flat spray tips ( $0.5 \mathrm{~m}$ between tips), with a spray volume equivalent to $200 \mathrm{~L} \mathrm{ha}^{-1}$. The treatments were applied in stage 1 and 10, respectively, with ambient humidity of 58.50 and $63.70 \%$, atmospheric air temperature of 19.95 and $22.23^{\circ} \mathrm{C}$, and wind speed of 3.50 and $2.53 \mathrm{~km} \mathrm{~h}^{-1}$.

The cultivar TBIO Sintonia was sown in the field on May 29, 2015 at a density of 330 plants $\mathrm{m}^{-2}$ with the help of a 9 $m$ standard profile rotary distributor and the incorporation of seeds into the soil was done with a "correntão". Broad sowing and high seed density was used in order to minimize weed incidence in the area, so any changes in the wheat plants were not influenced by possible interspecific competition. Because this is an area cultivated with wheat after the potato crop (Solanum tuberosum L.), and therefore with high nutrient contents, no fertilization was used at seeding. For top dressing, $250 \mathrm{~kg} \mathrm{ha-1}$ of $\mathrm{N}-\mathrm{P}_{2} \mathrm{O}_{5}-\mathrm{K}_{2} \mathrm{O}$ (23-00-18) was used. A growth regulator application (Moddus ${ }^{\circ}-0.5 \mathrm{~L} \mathrm{ha}^{-1}$ ) was made when the wheat plants presented the first visible node.

Pest and disease management for irrigated wheat crop was performed according to Kuhnem et al. (2020) and water management via central pivot was performed according to the crop water demand for the Alto Paranaíba region, MG, Brazil.

The SPAD (Soil Plant Analysis Development) index and phytotoxication assessments were performed at 14, 21, 28, and 35 days after SA application. To measure the SPAD index we used a portable chlorophyllometer (CFL1030) and the evaluations of the visual symptoms of intoxication of the wheat plants were based on a scale, in which $0 \%$ indicated the absence of damage and $100 \%$ represented the death of the plants, according to the methodology proposed by the SBCPD (1995).

The mechanized harvest was performed with a plot harvester 109 days after sowing, collecting the useful area of each plot, with yield correction to $13 \%$ humidity. The plants were subjected to tracing and the mass of one thousand grains was quantified, as well as the hectoliter weight (HW) determined through the mass of grains in $250 \mathrm{~mL}$, expressed in $\mathrm{kg} \mathrm{hL}^{-1}$, using a specific scale, and the grain yield, with the results being transformed into tha- ${ }^{-1}$.

The data were submitted to the analysis of variance by $F$ test and the averages were compared by Tukey test $(p<0.05)$.

\section{Results and Discussion}

No phytoxication symptoms caused by salicylic acid (SA) application were observed at both stages of wheat plants (data not shown). When evaluating SA application as an attenuator of herbicide phytotoxication in soybean (Dias et al., 2019) and wheat (Dias et al., 2017), these authors found no symptoms in SA treated plants, demonstrating the feasibility for its use.

The application of SA positively influenced the values of the SPAD index, and regardless of the stage and periods evaluated, the values were higher than the control treatment (no SA) (Figure 1). At 14 days after application (DAA) both at stage 1 and 10 in the highest dose of SA (1.0 mM), higher values were noted for this index in comparison to the other treatments. For this same dose, the values for the SPAD index were higher at the end of the vegetative stage.

The chlorophyll meter quantitatively assesses the leaf's green intensity by measuring light transmissions at 650 $\mathrm{nm}$ (the length where light absorption by the chlorophyll molecule occurs) and at $940 \mathrm{~nm}$ (where no absorption occurs). With these two values, the equipment processes a number, i.e. the SPAD index, which is usually correlated with the leaf's chlorophyll concentration (Klooster et al., 2012) and consequently can impact the crop's photosynthetic rate and grain yield.

In wheat plants subjected to application of 0.25 and 2.5 mM SA there was an increase in chlorophyll content (Chen et al., 2016). SA plays an important role in regulating plant growth and development, yet the biochemical processes surrounding most of these responses remain unknown (RivasSan Vicent \& Plasencia, 2011). Among the physiological and biochemical transformations in plants in response to SA application, increases in chlorophyll levels are cited (Kalaki et al., 2014). According to Fioreze \& Rodrigues (2012) there is a positive correlation between plant regulators and the SPAD index. In flowers of carnation (Dianthus caryophyllus L. cv. White.) (Kazemi et al., 2012), strawberry (Fragaria $x$ ananassa Duch. cv. Festival) (Youssef et al., 2017) and tomato (Solanum lycopersicum L.) (Hayat et al., 2008) foliar application of SA

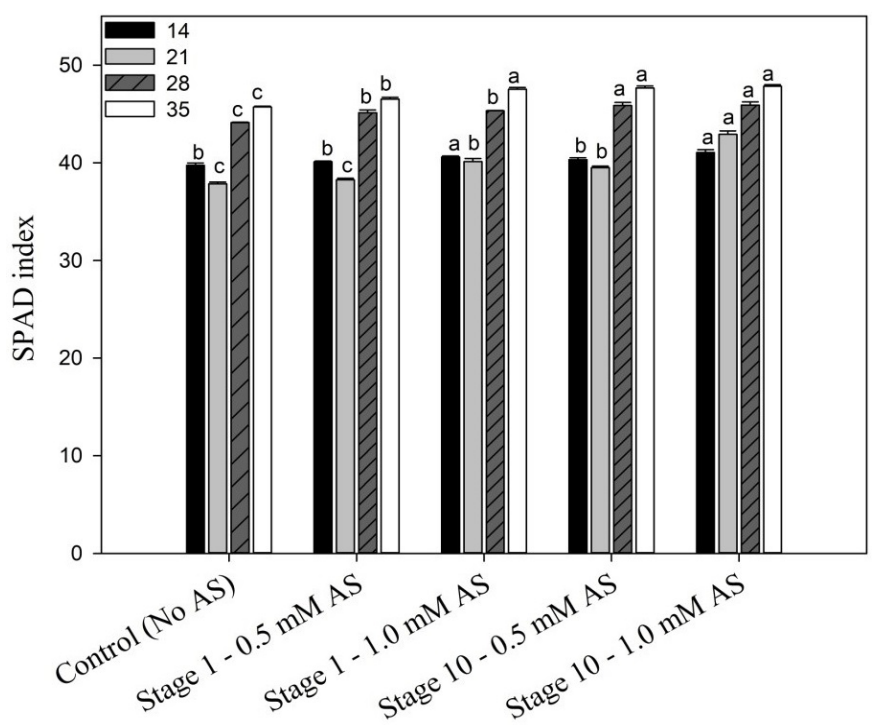

Averages followed by the same letter, for each moment of evaluation, do not differ by the Tukey test at $5 \%$ probability significance level. Vertical bars represent standard error of the average $(n=4)$.

Figure 2. SPAD index in wheat leaves evaluated at 14, 21, 28, and 35 days after the application of treatments. 
increased the SPAD index for example, thus demonstrating direct effect of SA application and for this parameter.

When analyzing the hectoliter weight ( $\mathrm{HW})$, mass of 1,000 grains $(\mathrm{g})$ and grain yield, it was found that the responses were positive for the application of SA, and it was higher when applied at the end of the vegetative cycle, regardless of the dose (Figure 3). It is worth noting that both the HW, used in marketing and the mass of 1,000 grains are associated with grain characteristics such as shape, tegument texture, size, and weight, thus being tools that can be important in the evaluation of exogenous compounds applied and their effects on wheat crop.

SA application promoted increases in nutraceutical quality for example of tomato (Vázquez Diaz et al., 2016) and orange such as sugars and organic acids for example (Ahmad et al., 2013). Chen et al. (2016) indicated that the increase in grain quality can be attributed to the increased photosynthetic activity provided by SA application and a greater availability of photoassimilate translocation to the commercial part of interest, which explains this positive effect on $\mathrm{HW}$ and thousand-grain mass in wheat. This data is in agreement with that found by Tejeda et al. (1998), who found increased HW values and grain yield at doses of $10^{-4}, 10^{-5}$, and $10^{-6} \mathrm{M}$ of SA in wheat plants. According to these authors, these variables directly indicate the influence on grain yield and this can be attributed to a favorable response of salicylates.

The increase in grain yield and the components already presented is due to the application of SA, since in plants, in addition to being related to the structure and levels of chlorophyll, it also helps the activity of enzymes such as Rubisco, carbonic anhydrase (CA) and nitrate reductase (NR) (Rivas-San Vicente \& Plasencia, 2011), and positively influences the transport of electrons in photosystem II (Janda et al., 2012), which are directly related to photosynthesis, this explains the increase in quality and yield components. Hayat et al. (2005) found increased CA and NR contents in wheat plants subjected to SA application. Photosynthetic activity is an important physiological process in plants and is directly related to grain yield. Sánchez-Chávez et al. (2011), found up to $59 \%$ increase in photosynthesis in pepper plants treated with $0.1 \mathrm{mM} \mathrm{SA}$. Wheat plants subjected to water stress after salicylic acid application had increased grain yield (Sharafizad et al., 2012; Sharma et al. 2017).

Additionally, the increase in sugar and protein content is stimulated by SA application (El Tayeb \& Ahmed, 2010) and similarly accelerates apical meristem cell division and root cell length (Shakirova et al., 2003), which directly stimulates the growth of SA treated plants. Tucuch-Haas et al. (2015) found positive response to growth and development components of wheat plant subjected to SA application. Similar results were reported by Zamaninejad et al. (2013) who found increased corn grain yield subjected to foliar application of SA.

It is worth discounting that the effect of SA on photosynthesis may also be related to its antioxidant effect. SA modulates the activity of antioxidant enzymes, which may act in the degradation of free radicals generated during
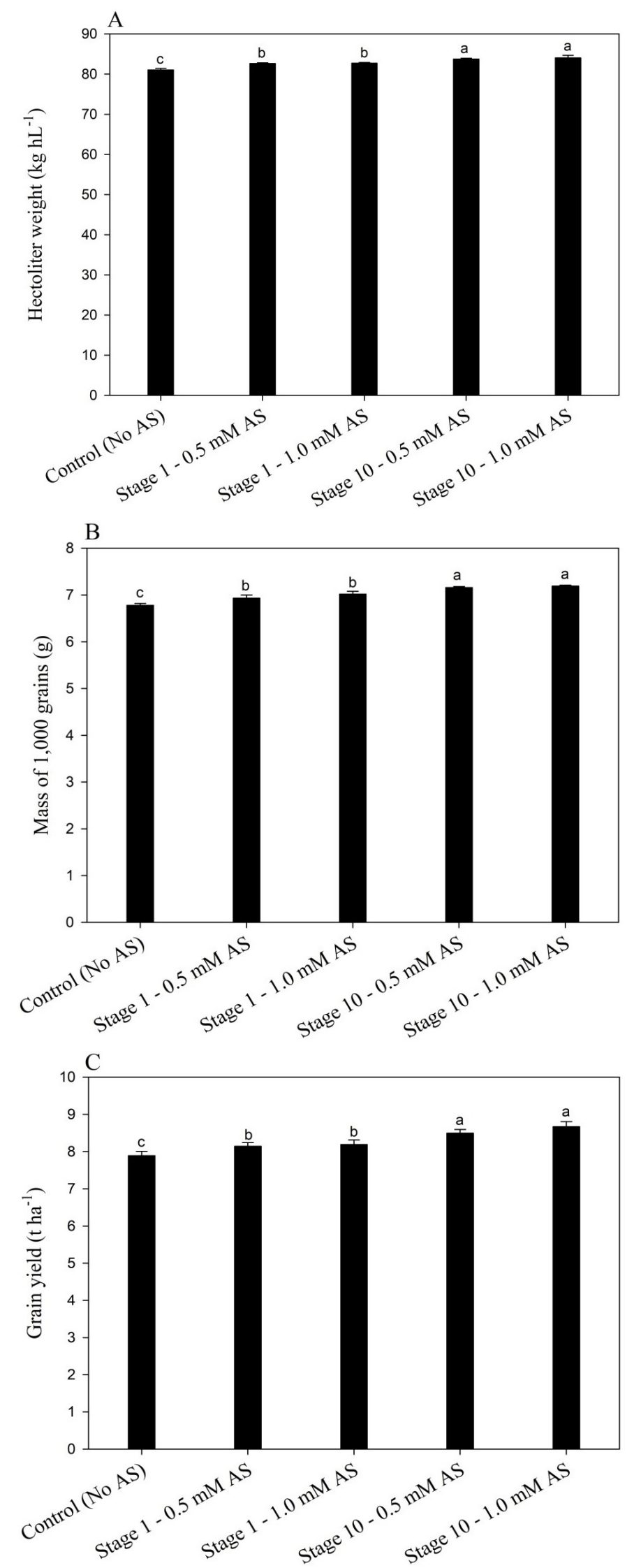

Averages followed by the same letter do not differ by Tukey's test at $5 \%$ probability significance level. Vertical bars represent standard error of the average $(n=4)$.

Figure 3. Hectoliter weight $(\mathrm{HW})\left(\mathrm{kg} \mathrm{hL}^{-1}\right)-\mathrm{A}$, mass of 1,000 grains $(\mathrm{g})$ - $\mathrm{B}$ and grain yield $\left(\mathrm{t} \mathrm{ha} \mathrm{a}^{-1}\right)-\mathrm{C}$ as a function of treatment application. 
photosynthetic activity. Plants that have high concentrations of SA increase glutathione levels and reduce stress levels (Mateo et al., 2006). Chen et al. (2016) demonstrated that the use of SA in wheat plants protected the photosynthetic apparatus by antioxidant capacity and verified the increase in antioxidant enzymes peroxidase (POD), superoxide dismutase (SOD), catalase (CAT), glutathione peroxidase (GPX), ascorbate peroxidase (APX) and glutathione reductase (GR).

Another important factor is that foliar application of SA favors greater accumulation and uptake of ions in the soil due to its greater area of exploration (Tucuch-Haas et al. 2016), so the effect of increasing nutrient contents is an important factor in explaining the positive effect on increased grain yield and seed quality. Villanueva-Couoh et al. (2009) found increased accumulation of nitrogen, phosphorus, and potassium after SA application to pepper, chrysanthemum, and bean plants.

When analyzing the effect of application at different stages of wheat plants, it is important to note that both doses of SA provided increased $\mathrm{PH}$, thousand-grain mass, and grain yield compared to the control. However, the application at stage 10 (budbreak) provided greater increments for the variables evaluated. According to Taiz et al. (2017), some plants can metabolize various plant regulators immediately and use for their growth and development and/or other functions, thus, the application of SA performed at the beginning of vegetative growth, did not reflect the effects as in the application at the end of vegetative growth. However, it is worth noting the scarcity of studies that evaluate the responses to plant regulars such as SA applied at different plant stages. According to Akbulut (2015), the use of SA as an elicitor produces various effects in plants, so the nature of these responses depends on the species, the stage of plant development, the dosage used, and the time of exposure to the treatment.

The results show that exogenous application of SA shows positive effects on grain yield and grain yield components of wheat and that the effect is greatest at the most advanced stage of vegetative growth. This study confirms the potential and importance of this molecule as a plant regulator, demonstrating the response under field conditions for the wheat crop under specific growing conditions.

\section{Conclusions}

Wheat under specific growing conditions responds positively to exogenous application of salicylic acid (SA), increasing the SPAD index, hectoliter weight, 1,000-grain mass, and grain yield.

Application of SA at stage 10 of vegetative growth of wheat plants increases the grain yield components of the wheat crop.

\section{Compliance with Ethical Standards}

Author contributions: Conceptualization: CADM, DVS, MRR; Formal analysis: RCD, CADM; Investigation: RCD, CADM;
Methodology: RCD, CADM; Project administration: CADM; DVS, MRR; Resources: DVS, MRR; Supervision: DVS, MRR; Visualization: LT, PVS; Writing - original draft: RCD, CADM, LT, PVS, DVS, MRR.

Conflict of interest: The authors declare that there is no conflict of interest that could interfere with the impartiality of this scientific work.

Funding: Not applicable.

\section{Literature Cited}

Ahmad, S.; Singh, Z.; Khan, A. S; lqbal, Z. Pre-harvest application of salicylic acid maintain the rind textural properties and reduce fruit rot and chilling injury of sweet orange during cold storage. Pakistan Journal of Agricultural Sciences, v.50, n.4, p.559-569, 2013. https://pakjas.com.pk/searchresult.php. 18 Feb. 2021.

Akbulut, G. B.; Yigit, E.; Bayram, D. Investigation of the effects of salicylic acid on some biochemical parameters in Zea mays to glyphosate herbicide. Journal of Environmental \& Analytical Toxicology, v.5, n.3, p.271-279, 2015. https://doi. org/10.4172/2161-0525.1000271.

Chen, Y. E.; Cui, J. M.; Li, G. X.; Yuan, M.; Zhang, Z. W.; Yuan, S.; Zhang, H. Y. Effect of salicylic acid on the antioxidant system and photosystem II in wheat seedlings. Biologia plantarum, v.60, n.1, p.139-147, 2016. https://doi.org/10.1007/s10535-015-0564-4.

Companhia Nacional de Abastecimento - Conab. Acompanhamento de safra brasileira de grãos. v.8 - Safra 2020/21, n.5 - Quinto levantamento. Brasília: Conab, 2021. 95 p. https://www.conab. gov.br/info-agro/safras/graos/boletim-da-safra-de-graos/item/ download/35818_f9638f460b06b8d623d8963949bb1aa0. 08 Feb. 2021.

Dias, R. C.; Bianchi, L.; Batista, T. B.; Germino, G, H.; Carbonari, C. A.; Ono, E. O.; Rodrigues, J. D.; Velini, E. D. Ácido salicílico e acibenzolar-S-methyl como atenuadores de fitointoxicação causada pelo chlorimuron-ethyl na cultura da soja. Revista de Ciências Agrárias, v.42, p.2, p.430-439, 2019. https://doi. org/10.19084/rca.16051.

Dias, R. C.; Melo, C. A. D.; Dos Santos, L. P. D.; Da Silva, G. S.; Carneiro, G. D. O. P.; Reis, M. R. Ácido salicílico como atenuador de fitotoxicidade causada pelo flumioxazin na cultura do trigo. Revista de Ciências Agrárias Amazonian Journal of Agricultural and Environmental Sciences, v.60, n.2, p.152-157, 2017. https:// doi.editoracubo.com.br/10.4322/rca.2458.

El Tayeb, M. A.; Ahmed, N. L. Response of wheat cultivars to drought and salicylic acid. American-Eurasian Journal of Agronomy, v.3, n.1, p.1-7. 2010. https://idosi.org/aeja/3(1)10/1.pdf. 18 Jan. 2021.

Empresa Brasileira de Pesquisa Agropecuária - Embrapa. Centro Nacional de Pesquisa Agropecuária de Solos. Sistema brasileiro de classificação de solos. Brasília: Embrapa Produção de Informação; Embrapa Solos, 2013. 154p.

Fioreze, S. L.; Rodrigues, J. D. Efeito da densidade de semeadura e de reguladores vegetais sobre os caracteres morfofisiológicos da folha bandeira do trigo. Revista Brasileira de Ciências Agrárias, v.7, n.1, p.89-96, 2012. https://doi.org/10.5039/agraria.v7i1a1594. 
Hayat, Q.; Hayat, S.; Alyemeni, M. N.; Ahmad, A. Salicylic acid mediated changes in growth, photosynthesis, nitrogen metabolism and antioxidant defense systemic Cicer arietinum L. Plant, Soil and Environment, v.58, n.9, p.417-423, 2010b. https:// doi.org/10.17221/232/2012-PSE.

Hayat, Q.; Hayat, S.; Irfan, M.; Ahmad, A. Effect of exogenous salicylic acid under changing environment: A review. Environmental and Experimental Botany, v.68, n.1, p.14-25, 2010a. https://doi. org/10.1016/j.envexpbot.2009.08.005.

Hayat, S.; Fariduddin, Q.; Ali, B.; Ahmad, A. Effect of salicylic acid on growth and enzyme activities of wheat seedlings. Acta Agronomica Hungarica, v.53, n.4, p.433-437, 2005. https://doi. org/10.1556/aagr.53.2005.4.9.

Hayat, S.; Hasan, S. A.; Fariduddin, Q.; Ahmad, A. Growth of tomato (Lycopersicon esculentum) in response to salicylic acid under water stress. Journal of Plant Interactions, v.3, n.4, p.297-304, 2008. https://doi.org/10.1080/17429140802320797.

Janda, K.; Hideg, E.; Szalai, G.; Kovács, L.; Janda, T. Salicylic acid may indirectly influence the photosynthetic electron transport. Journal of Plant Physiology, v.169, n.10, p.971-978, 2012. https:// doi.org/10.1016/j.jplph.2012.02.020.

Kalaki, G. S.; Abdosi, V.; Boojar, M. M. A. Change in chlorophylls composition and some morphological attributes of strawberry (Fragaria $\times$ ananassa Duch cv. Camarosa) in response to salicylic acid spray. International Journal of Biosciences, v.5, n.12, p.2042011, 2014. https://doi.org/10.12692/ijb/5.12.204-211.

Kang, G.; Li, G.; Guo, T. Molecular mechanism of salicylic acidinduced abiotic stress tolerance in righer plants. Acta Physiologiae Plantarum, v.36, n.9, p.2287-2297, 2014. https:// doi.org/10.1007/s11738-014-1603-z.

Kazemi, M.; Hadavi, E.; Hekmati, J. Effect of salicylic acid, malic acid, citric acid and sucrose on antioxidant activity, membrane stability and ACCoxidase activity in relation to vase life of carnation cut flowers. Journal of Agricultural Technology, v.8, n.6, p.2053-2063, 2012. https:// scialert.net/fulltext/?doi=jps.2012.78.84\&org=10. 18 Mar. 2020.

Khodary, S. E. A. Effect of salicylic acid on the growth, photosynthesis and carbohydrate metabolism in salt stressed maize plants. International Journal of Agriculture \& Biology, v.6, n.1, p.5-8, 2004. https://inis.iaea.org/search/searchsinglerecord.aspx?reco rdsFor=SingleRecord\&RN=35053879. 07 Dec. 2020.

Klooster, W. S.; Cregg, B. M.; Fernandez, R. T.; Nzokou, P. Growth and physiology of deciduous shade trees in response to controlledrelease fertilizer. Scientia Horticulturae, v.35, p.71-79, 2012. https://doi.org/10.1016/j.scienta.2011.12.009.

Kuhnem, P.; Rosa, A.C.; Wagner, F.; Rosa, A.T.S. (Eds.). Informações técnicas para trigo e triticale - Safra 2020. Passo Fundo: Embrapa, 2020. 256p.

Large, E. C. Growth stages in cereais. Plant Pathology, v.3, n.1, p.128129, 1954. https://doi.org/10.1111/j.1365-3059.1954.tb00716.x.

Larqué-Saavedra, A.; Martín-Mex, R.; Nexticapan-Garcéz, Á.; VergaraYoisura, S.; Gutiérrez-Rendón, M. Efecto del ácido salicílico en el crecimiento de plántulas de tomate (Lycopersicon esculentum Mill.). Revista Chapingo. Serie Horticultura, v.16, n.3, p.183187, 2010. http://www.scielo.org.mx/scielo.php?script=sci_ arttext\&pid=S1027-152X2010000300006\&lng=es\&nrm=iso\&tln g=es. 05 Nov. 2020.
Marini, N.; Tunes, L.M.; Silva, J.I.; De Moraes, D. M.; Olivo, F.; Cantos, A. A. Efeito do fungicida Carboxim Tiram na qualidade fisiológica de sementes de trigo (Triticum aestivum L.). Revista Brasileira de Ciências Agrárias, v.6, n.1, p.17-22, 2011. https://doi:10.5039/ agraria.v6i1a737.

Martín-Mex, R.; Nexticapan-Garcéz, A.; Herrera-Tuz, R.; Vergarayoisura, S. Y Larqué-Saavedra, A. Efecto positivo de aplicaciones de ácido salicílico en la productividad de papaya (Carica papaya). Revista Mexicana de Ciências Agrícolas, v.3, n.8, p.1637-1643, 2012. http:// www.scielo.org. $\mathrm{mx} /$ scielo.php?script=sci_arttext\&pid=S200709342012000800013\&lng=es\&nrm=iso\&tlng=es. 08 Nov. 2020.

Martín-Mex, R.; Nexticapan-Garcéz, A.; Larqué-Saavedra, A. Potential benefits of salicylic acid in food production. In: Hayat, S.; Ahmad, A.; Alyemeni, M. N. (Eds.). Salicylic acid. Dordrecht: Springer, 2013. p. 299313. https://doi.org/10.1007/978-94-007-6428-6_13.

Mateo, A.; Funck, D.; Mühlenbock, P.; Kular, B.; Mullineaux, P. M.; Karpinski, S. Controlled levels of salicylic acid are required for optimal photosynthesis and redox homeostasis. Journal of Experimental Botany, v.57, n.8, p.1795-1807, 2006. https://doi. org/10.1093/jxb/erj196.

Mazzuchelli, E. H. L.; Souza, G. M.; Pacheco, A. C. Rustificação de mudas de eucalipto via aplicação de ácido salicílico. Pesquisa Agropecuária Tropical, v.44, n.4, p.443-450, 2014. https://doi. org/10.1590/s1983-40632014000400012.

Rivas-San Vicente, M.; Plasencia, J. Salicylic acid beyond defence: its role in plant growth and development. Journal of Experimental Botany, v.62, n.10, p.3321-3338, 2011. https://doi:10.1093/jxb/err031.

Rodrigues, O.; Teixeira, M. C. C. Bases ecofisiológicas para manutenção da qualidade do trigo. Passo Fundo: Embrapa Trigo, 2010. 84p.

Sánchez-Chávez, E.; Barrera-Tovar, R.; Muñoz-Márquez, E.; Ojedabarrios, D. L.; Anchondo-Nájera, A. Efecto del ácido salicílico sobre biomasa, actividad fotosintética, contenido nutricional del chile jalapeño. Revista Chapingo. Serie Horticultura, v.17, n.spe 1, p.63-66. 2011. http://www.scielo.org.mx/scielo.php?script=sci_arttext\&pid=S1027152X2011000400010\&lng=es\&nrm=iso\&tlng=es. 07 Dec. 2020.

Shakirova, F. M. Role of hormonal system in the manifestation of growth promoting and antistress action of salicylic acid. In: Hayat, S.; Ahmad, A. (Eds.). Salicylic acid: a plant hormone. Dordrecht: Springer, 2007, p. 69-89. https://doi.org/10.1007/1-4020-5184-0_4.

Shakirova, F. M.; Sakhabutdinova, A. R.; Bezrukova, M. V.; Fatkhutdinova, R. A.; Fatkhutdinova, D. R. Changes in the hormonal status of wheat seedlings induced by salicylic acid and salinity. Plant Science, v.164, n.3, p.317-322, 2003. https://doi:10.1016/s0168-9452(02)00415-6.

Sharafizad, M.; Naderi, A.; Siadat, S. A.; Sakinejad, T.; Lak, S. Effect of salicylic acid pretreatment on yield, its components and remobilization of stored material of wheat under drought stress. Journal of Agricultural Science, v.4, n.10, p.115-125, 2012. https://doi:10.5539/jas.v4n10p115.

Sharafizad, M.; Naderi, A.; Siadat, S. A.; Sakinejad, T.; Lak, S. Effect of salicylic acid pretreatment on germination of wheat under drought stress. Journal of Agricultural Science, v.5, n.3, p.179199, 2013. https://doi.org/10.5539/jas.v5n3p179.

Sharma, M.; Gupta, S. K.; Majumder, B.; Maurya, V. K.; Deeba, F.; Alam, A.; Pandey, V. Salicylic acid mediated growth, physiological and proteomic responses in two wheat varieties under drought stress. Journal of Proteomics, v.163, p.28-51, 2017. https://doi. org/10.1016/j.jprot.2017.05.011. 
Sociedade Brasileira da Ciência das Plantas Daninhas. Procedimentos para instalação, avaliação e análise de experimentos com herbicidas. Londrina: SBCPD, 1995. 42 p.

Taiz, L.;Zeiger, E.; Møller, I. M.; Murphy, A. Fisiologia e desenvolvimento vegetal. 6.ed. Porto Alegre: Artmed, 2017. 858p.

Tejeda, R. L.; Rodríguez, V. C.; Coronado, M. A. G. Aplicación de ácido salicílico para incrementar el rendimiento agronómico en tres variedades de trigo. Terra, v.16, n.1, p.43-48, 1998. https:// redalyc.org/articulo.oa?id=57316105. 05 Nov. 2020.

Tucuch-Haas, C. J.; Alcántar González, G.; Larqué Saavedra, A. Efecto del ácido salicílico en el crecimiento de la raíz y biomasa total de plántulas de trigo. Terra Latinoamericana, v.33, n.1, p.6368, 2015. http://www.scielo.org.mx/scielo.php?script=sci_ arttext\&pid=S0187-57792015000100063\&Ing=es\&nrm=iso\&tln g=es. 21 Dec. 2020.

Tucuch-Haas, C. J.; Alcántar-González, G.; Volke-Haller, V. H.; SalinasMoreno, Y.; Trejo-Téllez, L. I.; Larqué-Saavedra, A. Efecto del ácido salicílico sobre el crecimiento de raíz de plántulas de maíz. Revista Mexicana de Ciencias Agrícolas, v.7, n.3, p.709-716, 2016. http:// www.scielo.org.mx/scielo.php?script=sci_arttext\&pid=S200709342016000300709\&Ing=es\&nrm=iso\&tlng=es. 21 Dec. 2020.

Tucuch-Haas, C.; Alcántar-González, G.; Trejo-Téllez, L. I.; Volke-Haller, H.; Salinas-Moreno, Y.; Larqué-Saavedra, A. Efecto del ácido salicílico en el crecimiento, estatus nutrimental y rendimiento en maíz (Zea mays). Agrociencia, v.51, n.7, p.771-781, 2017. http:// www.scielo.org.mx/scielo.php?script=sci_arttext\&pid=S140531952017000700771\&lng=es\&nrm=iso\&tlng=es. 21 Dec. 2020.
Vázquez Diaz, D. A.; Salas Pérez, L.; Preciado Rangel, P.; Segura Castruita, M. Á.; González Fuentes, J. A.; Valenzuela-García, J. R. Efecto del ácido salicílico en la producción y calidad nutracéutica de frutos de tomate. Revista Mexicana de Ciencias Agrícolas, n.17, p.3405-3414, 2016. https://redalyc.org/articulo. oa?id=263149506002. 19 Jan. 2021.

Villanueva-Couoh, E.; Alcántar-González, G.; Sánchez-García, P.; Soriafregoso, M.; Larqué-Saavedra, A. Efecto del ácido salicílico y dimetilsulfóxido en la floración de Chrysanthemun morifolium (Ramat) Kitamura en Yucatán. Revista Chapingo. Serie Horticultura, v.15, n.spe, p.25-31, 2009. http://www.scielo.org. $\mathrm{mx} /$ scielo.php?script=sci_arttext\&pid=S1027-152X20090004000 05\&lng=es\&nrm=iso\&tlng=es. 11 Nov. 2020.

Youssef, S. M. S.; El-Azm, A.; Ibrahim, N. A.; Elhady, A.; Elhameid, S. A. Frequent foliar sprayings of salicylic acid with elevated concentrations enhance growth, yield and fruit quality of strawberry (Fragaria $x$ ananassa Duch. cv. Festival) plants. Egyptian Journal of Horticulture, v.44, n.1, p.61-74, 2017. https://doi.org/10.21608/ejoh.2017.1100.1008.

Zamaninejad, M.; Khorasani, S. K.; Moeini, M. J.; Heidarian, A. R. Effect of salicylic acid on morphological characteristics, yield and yield components of corn (Zea mays L.) under drought condition. European Journal of Experimental Biology, v.3, n.2, p.153-161, 2013. https://www.imedpub.com/articles/effect-ofsalicylic-acid-on-morphological-characteristics-yield-and-yieldcomponents-of-corn-zea-mays-I-under-drought-condition.pdf. 07 Dec. 2020. 